\title{
EASTERN EUROPE BEFORE THE WORLD COURT: “THUMBELINA” OF THE INTERNATIONAL LEGAL ORDER? ${ }^{* *}$
}

\begin{abstract}
The cases referred to the World Court (the ICJ and he PCIJ) that arose as a consequence of the events which occurred in Eastern Europe, as well as some brilliant albeit mutually very different international jurists from this part of Europe, had a significant impact on the development of international law. The article provides strong evidence that the significance of Eastern Europe issues and the Court judges coming from this region is highly disproportionate to the rather minuscule size of the Eastern European region. This importance is proven by several quantitative and qualitative indicators summarized in the concluding remarks of the article: the number of Eastern European cases brought before the Court, the number of Eastern European judges who served in the Court, the number of judges from Eastern Europe who were Presidents of the Court, the number of years during which Presidents of the Court were from Eastern Europe, the impact of some of the judges on the substance of key Court decisions, etc.
\end{abstract}

Keywords: International Court of Justice (ICJ), Permanent Court of International Justice (PCIJ), Eastern Europe, development of international law, ICJ judges.

\footnotetext{
*milos.hrnjaz@fpn.bg.ac.rs

${ }^{* *}$ This article is the result of research on the project "Political Identity of Serbia in a Global and Regional Context" (no.179076), funded by the Ministry of Education, Science and Technological Development of the Republic of Serbia.

Note: The author would like to thank Janja Simentić and participants at the Conference Institutions and International Law in Eastern Europe, organized by Leibniz Institute for the History and Culture of Eastern Europe, for their comments on the earlier version of this article.
} 
"I felt that a new visit to the world of thought in the field of international law may well be timely as in our day and age we are revisiting so many fields which have been tilled in the past and gleaning some overlooked insights. For teachings of the past are a part of the history, which in turn has an integrating character leading to the present. It is better not only to understand recent events in terms of contemporary scene, but also to view them as what they really are - a part of the world of thought as a whole in the dimension of time. But I do not propose to view that world as a self-contained, homogenous entity, an error so frequently committed in the past...

(Lachs, 1987: 1, emphasis added)"

\section{Introduction}

There is no consensus about the definition of Eastern Europe, partly because several criteria are used (geographical, political, historical, and a combination thereof) and partly because some of the states in this part of Europe are trying to prove that they are not part of this region. For the purpose of this paper, the UN regional division is used, according to which the following countries belong to Eastern Europe: Albania, Armenia, Azerbaijan, Belarus, Bosnia and Herzegovina, Bulgaria, Croatia, the Czech Republic, Estonia, Georgia, Hungary, Latvia, Lithuania, Montenegro, Poland, Republic of Moldova, Romania, the Russian Federation, Serbia, Slovakia, Slovenia, the Former Yugoslav Republic of Macedonia, and Ukraine. The main reason for accepting this UN regional division, notwithstanding all possible criticism, is the fact that this regional division is used during the process of electing the judges of International Court of Justice (ICJ), which is very important for the purpose of this article.

The term World Court is sometimes used to denote both the International Court of Justice and its predecessor - the Permanent Court of International Justice. The cases referred to this Court that arose as a consequence of the events which occurred in Eastern Europe, as well as some brilliant albeit mutually very different international jurists from this part of Europe, had a significant impact on the development of international law. The paper provides stong evidence of the great significance of Eastern Europe for the development of international law.

After the introduction, in the second part of the paper, the author analyses Eastern European cases brought before the World Court and disusses their influence 
on the development of international legal argument. The provided analysis of the practice of the Permanent Court of International Justice (PCIJ) reveals not only that "[t]he work of the Permanent Court... has changed the way in which international law is approached" (Spiermann, 2004: 33) but also the role of the Eastern European cases in this process. The author also discusses the influence of more recent Eastern European cases brought before the ICJ on the development of international law, with specific reference to the Genocide $\operatorname{cases}^{1}$ and the Kosovo Advisory Opinion. ${ }^{2}$ The third part of the article provides analysis of the working biographies and key contributions of the most important Eastern European judges of the World Court, in order to evaluate their impact on the development of international law. Research into their personal and working biographies discloses their important role in some of the trademark cases that appeared before the PCIJ and ICJ.

The paper provides strong evidence that the significance of Eastern Europe issues and judges of the World Court is highly disproportionate to the rather minuscule size of the Eastern European region. This importance is proven by several quantitative and qualitative indicators summarized in the concluding remarks: the number of Eastern European cases brought before the Court, the number of Eastern European judges who served in the Court, the number of judges from Eastern Europe who were Presidents of the Court, the number of years during which Presidents of the Court were from Eastern Europe, and the impact of some of the judges on the substance of key Court decisions

\section{Eastern European cases before the World Court}

There are several ways to measure the influence of Eastern European cases referred to the World Court on the development of international law. One of them is the number of cases that were closely connected with this region. However, it is hard to provide the exact number of these cases. First of all, there is a problem with definition of Eastern Europe. More importantly, there are cases, such as Wimbledon case before PCIJ, in which Eastern European countries were not parties before the Court but where the interests of Eastern European countries were the main issue. ${ }^{3}$ We decided to include in this analysis all cases which have

1 International Court of Justice: Application of the Convention on the Prevention and Punishment of the Crime of Genocide (Croatia v. Serbia) (Judgment) [2015] ICJ Rep 3; International Court of Justice: Application of the Convention on the Prevention and Punishment of the Crime of Genocide (Bosnia and Herzegovina v. Serbia and Montenegro) (Judgment) [2007] ICJ Rep 43.

2 International Court of Justice: Accordance with International Law of the Unilateral Declaration of Independence in Respect of Kosovo (Advisory Opinion) [2010] ICJ Rep 403.

3 Permanent Court of International Justice, Case of the S.S. Wimbledon (Judgment) [1923] Series A. 
direct connection with the region of Eastern Europe. The second indicator for the influence of Eastern European cases on the development of international law could be their general significance for the development of international legal argument (Spiermann, 2004). Finally, one could determine the importance of Eastern European cases before the World Court by assessing their significance for the process of clarification of international legal rules. All of these indicators will be used in this section.

\subsection{Cases before the PCIJ}

At first glance, the percentage of Eastern European cases before the Permanent Court of International Justice (PCIJ) is striking. Approximately 50\% of all the cases (contentious proceedings and advisory opinions) of this Court were closely connected with Eastern Europe (Fitzmaurice, Tams, 2013). Most of them involved Poland, either because it was a party to the proceedings or because advisory opinions concerned Polish interests. There are, of course, some logical historical explanations of this fact. First of all, the PCIJ was almost exclusively a court used for the settlement of European disputes. Second, in the interwar period, Poland found itself in an extremely complex situation: its borders had been shaped from 1918 to 1923; its relations with two big and dangerous neighbour-states (Soviet Union and Germany) were fragile; and its internal complexities were difficult to cope with (Prazmowska, 2011:159-182; Davies, 2005).

The high percentage of Eastern European cases before the PCIJ is exceptionally important because this was actually the first standing international court with significant jurisprudence (there were some previous judicial institutions but they were rather regional, unsuccessful institutions, such as the Central American Court of Justice (1907-1917), or they never started working, such as the International Prize Court). Therefore, the PCIJ's task was not only to apply the norms but also to structure international legal argument: "The structures of international legal argument then used were not a result of the interbellum, its political or other circumstances; they are part of a conceptual deep structure ingrained in internationalism at all times" (Spiermann, 2004: 394).

It is, of course, impossible to explain thoroughly here the contribution of the PCIJ to the development of international legal argument. Instead, it is possible to claim that the PCIJ mostly contributed to the development of rules concerning treaty interpretation and the legal reasoning behind these interpretations. One of the examples is the Danube opinion which contributed to the development of the principle of subordinated status of preparatory work in treaty interpretation: "There is no occasion to have regard to the protocols of the conference at which a convention was negotiated in order to construe a text which is suffi- 
ciently clear in itself ${ }^{\prime 4}$ (Fachiri, 1929). Article 32 of the Vienna Convention of Law of Treaties confirms the applicability of this principle by stipulating that preparatory work of the treaty and the circumstances of its conclusion are supplementary means of interpretation. Additionally, cases such as Jaworzina ${ }^{5}$ and Monastery of Saint Naoum ${ }^{6}$ contributed to the understanding of the leading role given to territorial sovereignty in the interpretation of international treaties. After the 1930s, the PCIJ entered a new phase of the treaties' interpretation, which was demonstrated, inter alia, in the Treatment of Polish Nationals ${ }^{7}$ opinion (Spiermann, 2004: 348).

The PCIJ even contributed, albeit mostly indirectly, to understanding the fundamental concepts of international law (Steiner, 1936). Namely, one should bear in mind the fact that international law was not as developed after the First World War as it is today. The number of rules and even areas that international law covered was indeed modest, especially compared with contemporary international law. Therefore, the Court's task of interpreting international law rules and developing international law was of fundamental importance.

H. A. Steiner, for example, noted several contributions of the Court to the development of basic international law concepts (only the Eastern European cases will be discussed here). Steiner noticed the importance of the Court's jurisprudence for the issues such as the nature of international law and Court jurisdiction (the Chorzow $^{8}$ case), the rights of private individuals notwithstanding the fact that Court has jurisdiction only in interstate cases (German Settlers in Poland', Serbian Loans ${ }^{10}$ ), the thorough, albeit sometimes controversial, explanation of the concept of sovereignty (Wimbledon ${ }^{11}$, Jaworzina, Danube), the relationship between in-

4 Permanent Court of International Justice, Jurisdiction of the European Commission on the Danube (Advisory Opinion) [1927] Series B, p. 28.

5 Permanent Court of International Justice, Question of Jaworzina (Advisory Opinion) [1923] Series B.

6 Permanent Court of International Justice, Question of Monastery Saint-Naoum (Advisory Opinion)[1924] Series B.

7 Permanent Court of International Justice, Treatment of Polish Nationals and other Persons of Polish Origin or Speech in the Danzig Territory (Advisory Opinion) [1932] Series A/B.

8 Permanent Court of International Justice, Case Concerning the Factory at Chorzow (Merits) [1928] Series A.

9 Permanent Court of International Justice, German Settlers in Poland (Advisory Opinion) [1923] Series B.

10 Permanent Court of International Justice, Case Concerning the Payment of Various Serbian Loans Issued in France (Judgment) [1929] Series A.

11 Permanent Court of International Justice, Case of the S.S. Wimbledon (Judgment) [1923] Series A. 
ternational and municipal law where the Court firmly argued for strict judicial dualism according to which international and national law are two separate systems of law (the Greeco-Bulgarian ${ }^{12}$ case, Serbian Loans), etc. (Steiner, 1936).

\subsection{The cases before the ICJ}

The number of Eastern European cases before the International Court of Justice (ICJ) is hardly comparable with that of the cases that appeared before the PCIJ. It has already been mentioned that about $50 \%$ of the PCIJ cases were closely connected to the issues of Eastern Europe, while the ICJ dealt with only 5 to $10 \%$ of such cases (it is not easy to state exact figure since Yugoslavia formally made 10 applications against some NATO countries as a consequence of the NATO's 1999 armed intervention). There are a number of reasons for this decrease, but the most important is probably the globalisation of international affairs and consequently international law. Although this process had begun in the interwar period, its full consequences became obvious only after the Second World War. Decolonisation and the emergence of numerous new states were important segments of this process. Another important reason was the Cold War and the fact that Eastern Europe was under the Soviet sphere of influence (the ICJ has never issued a ruling in a case in which Soviet Union was one of the parties).

Be that as it may, the relatively small number of Eastern European cases that appeared before the ICJ does not mean that they were not important for the interpretation of the legal rules in particular areas of international law. Actually, the very first contentious case brought before the newly created ICJ was the famous Corfu Channel case; it involved one Eastern European country - Albania, and one Western European country - the United Kingdom. There is a number of reasons why this case was so important for the jurisprudence of the Court: the issue of the Court's jurisdiction and further clarification of the role of consent in this sense, the question of evidence before the Court (Del Mar, 2012), law of the sea and especially the concept of innocent passage (McLaughlin, 2012), international liability and necessary compensation (D’Argent, 2012), and development of environmental law principles (Bannelier, 2012). One should also recall the brave, albeit controversial, incorporation of "...certain general and well-recognised principles, namely: elementary considerations of humanity, even more exacting in peace than in war"13 as grounds for the liability of Albania. Still, the Court's famous dictum on the prohibition of intervention was arguably the

12 Permanent Court of International Justice, Greco-Bulgarian "Communities" (Advisory Opinion) [1930] Series B.

13 International Court of Justice, Corfu Channel case (United Kingdom v. Albania (Judgment), [1949], ICJ Rep 22. 
most important legacy of the Corfu Channel case. The principal judicial institution of the UN sent a clear message on this issue to the more powerful states:

"The Court can only regard the alleged right of intervention as the manifestation of a policy of force, such as has, in the past, given rise to most serious abuses and such as cannot, whatever be the present defects in international organisation, find a place in international law". ${ }^{14}$

The Corfu Channel case remained one of the most cited cases in the jurisprudence of the ICJ, actually just behind the famous Nicaragua case (Bedjaoui, 2012). It is interesting to note that it was also cited in the Eastern European case that appeared next before the Court - the Genocide Case involving Bosnia and Herzegovina and Yugoslavia (later Serbia). This was one of the longest and most complex cases in the Court's history - Bosnia and Herzegovina made an Application in 1993 and the Court delivered the Judgment in 2007.

The significance of the Genocide Case for the development of international law and the Court's practice is immense. First of all, this was the first judgment interpreting the responsibility of states for the breach of the Convention on the Prevention and Punishment of the Crime of Genocide (1948) and, at the same time, the first judgment that pronounced one state responsible for the violation of the Convention. Additionally, this case gave the Court an important opportunity to clarify certain key concepts of the crime of genocide itself: the scope of mens rea and actus reus (Kress, 2007), the nature of liability of states for committing the crime of genocide (Milanovic, 2007), the interpretation of the concept of obligation to prevent genocide (Gattini, 2007), and the interpretation of the terms protected group and the part of the group which are parts of the genocide definition from the Convention ${ }^{15}$. Finally and more generally, the judgment was important because of the issue of Court's jurisdiction, the issue of evidence presented before the Court, and the relationship between the ICJ and other international courts - more specifically, that with the ICTY (Cassese, 2007).

This was not, however, the only Eastern European genocide case that appeared before the ICJ. Namely, Croatia also initiated a case against Yugoslavia (later Serbia) for violation of the Genocide Convention. The Court delivered judgments on both the memorial of Croatia and the counter-memorial of Serbia in 2015, sixteen years after Croatia had filed the application against Yugoslavia and six years after Serbia submitted counter-memorial in the same case. In this case, the Court additionally had to explain the relation between two concepts: ethnic cleansing and the crime of genocide (Steinfeld, 2015). Furthermore, the Court

14 Ibidem, p. 35.

15 The Genocide case (Bosnia and Hercegovina v. Yugoslavia), para. 191-201. 
offered further clarification concerning the standard of proof for the second element of the genocide crime, dolus speciallis (Behrens, 2015).

On the other hand, The Maritime Delimitation in the Black Sea case, involving Romania and Ukraine, did not provoke many controversies. Namely, the Court had already had a highly developed practice in this area, so it was not realistic to expect any significant development of the law of the sea. Nevertheless, in this case, the Court decided not to use the coast of the Serpents' Island for the delimitation stage. According to some authors, this decision of the Court will "give parties to the future delimitation cases additional arguments regarding the role of small features in delimitations, as well as rationales for their elimination" (Bederman, Lathorp, 2009).

All previously mentioned Eastern European cases before the ICJ were contentious ones. The Court, however, delivered a couple of important advisory opinion too: the Advisory Opinion on the Interpretation of Peace Treaties with Bulgaria, Hungary and Romania ${ }^{16}$, as well as the Advisory Opinion on the Declaration of Independence of Kosovo. ${ }^{17}$ The former Advisory Opinion concerned the analysis of the procedure to be adopted regarding the settlement of disputes between Allied States on the one hand and Romania, Bulgaria and Hungary on the other according to the Peace treaties between these countries in 1947. The Advisory Opinion was important not only because of the complicated Cold War context but also because of the Court's ruling on several issues such as: the rules of procedure in arbitration cases, the scope of ICJ jurisdiction in Advisory proceedings, as well as the relationship between the issue of human rights and Article 2 (7) of the UN Charter (non-intervention of the UN institutions within essentially domestic affairs of UN members). Over the two phases of the Advisory Opinion, the Court ruled that Romania, Bulgaria and Hungary violated the rules of procedure on the settlement of disputes stipulated in the peace treaties, but it is interesting to note that three judges from Eastern Europe countries dissented in this case..$^{18}$

Notwithstanding the fact that the size of Kosovo is only $1.5 \%$ of the territory of Texas and that its population consists of fewer than 2,000,000 people, expectations from the Court in the Advisory Opinion on Kosovo were high. There were 36 written statements of states and a written contribution of the authors of the unilateral Declaration of Independence (authors of the unilateral Declaration of

16 International Court of Justice, Interpretation of Peace Treaties (Advisory Opinion) [1950] ICJ Rep 65.

17 Accordance with International Law of the Unilateral Declaration of Independence in Respect of Kosovo, supra note 2.

18 Judges Zoricic, Winiarski and Krylov. Their dissenting opinions are available at: http:// www.icj-cij.org/en/case/8/advisory-opinions. 
Independence was the official name of the Kosovo institutions before the Court). That is the second largest number of states that decided to submit written statements to the Court in an advisory proceeding (the largest number of written submissions was lodged in the famous Wall ${ }^{19}$ opinion).

Argentina nicely sublimed the reasons for the international community's interest in this case: "The question put before the Court regards a wide range of issues of particular importance not only for the maintenance of peace and security in the region concerned but also with regard to fundamental principles of international law and to the respect thereof, which are of general concern". ${ }^{20}$ Argentina, most of the other states that participated in this case, as well as the international law doctrine expected the ICJ to finally offer an authoritative interpretation of the relation between the general principles of international law - especially that between sovereignty and self-determination of peoples (Hrnjaz, 2012). In its written submission, Slovenia openly recognised a possible contradiction between these two principles:

"When the 'right of a state' to protect its territorial integrity and the 'right of people' to decide upon their own destiny are in conflict, the right of people prevails, alongside the peaceful settlement of disputes, in particular through negotiations. In recent decades, the right to self-determination as a human right has been given precedence over the principle of respect for the territorial integrity of states". ${ }^{21}$

Bearing all this in mind, one should not be surprised by a general sense of disappointment with the final ruling of the Court, in which the question posed by the UNGA was interpreted narrowly (Milanovic, Wood, 2015). Namely, the Court refused to deal with the key issues of this dispute, such as the Kosovo statehood and the legal effect of the states' recognition of Kosovo:

"In the present case, the question posed by the General Assembly is clearly formulated. The question is narrow and specific; it asks for the Court's opinion on whether or not the declaration of independence is in accordance with international law. It does not ask about the legal consequences of that declaration. In particular, it does not ask whether or not Kosovo has achieved statehood. Nor

19 International Court of Justice, Legal Consequences of the Construction of the Wall in the Occupied Palestinian Territory (Advisory Opinion) [2004] ICJ Rep 136.

20 International Court of Justice, Accordance with International Law of the Unilateral Declaration of Independence in Respect of Kosovo, Written Statement of Argentina, p. 5. Available at: http://www.icj-cij.org/files/case-related/141/15666.pdf.

21 Kosovo Advisory Opinion, Written Statement of Slovenia, p. 2. Available at: http://www. icj-cij.org/files/case-related/141/15696.pdf. 
does it ask about the validity or legal effects of the recognition of Kosovo by those States which have recognized it as an independent State."22

The value of the Advisory Opinion on Kosovo is, however, hidden in the written submissions of the states, because these can be viewed as evidence of existence or lack of existence of the opinio iuris as one of the elements of customary international norms applying to sovereignty and self-determination of peoples. In this proceeding, for example, a number of states supported the concept of remedial secession, even though this concept is weakly supported by the formal sources of international law; (it is probably interesting to note that Russia was one of them, although the general feeling prevails that this concept is mostly supported by the Western countries or the Global North countries). Albania, Slovenia, Czech Republic, Latvia, Estonia and Poland were among those countries that used the argument of remedial secession in this Advisory Opinion (Hrnjaz, 2012).

\section{Eastern European judges in the World Court and the development of international law}

The PCIJ and the ICJ are both collegiate bodies, deciding by majority vote, and it is thus difficult to evaluate the contribution of individual judges to the development of international law, if any. The beginning of this section will provide an answer to the following question: who are, generally speaking, international judges? Afterwards, a table with Eastern European judges of the World Court will be presented (Table 1), followed by several short illustrations of their contribution to the work of the Court.

One might believe that a proliferation of international courts made it more difficult to locate persons with a proper educational background and personal qualities to fill the numerous judicial positions. Historical research reveals, however, that finding a good judge has never been an easy task (Spiermann, 2004). The question is: what is it that actually makes a good judge? Should she or he, bearing in mind that women still represent a significantly smaller part of this community - between 20 and 25\% (Terris, Romano, Swigart, 2007), be an international law professor, a national judge, a diplomat, or something else?

Statutes of the courts usually stipulate minimal professional and personal requirements for judges. But, more often than not, candidates are nominated by their respective countries. This is followed by the election of the judges, and this phase is marked by "...particularly complex moments, where a number of considerations - like states' national interests, prestige and power politics, and the need to ensure representativeness - interact to eventually determine the result" (Terris, Romano, Swigart, 2007: 46).

22 Kosovo Advisory Opinion, para. 51. 
There are significant differences between the international courts regarding professional and personal requirements for judges, their nomination and election. Therefore, the focus will now be placed on the procedure in the ICJ. The Court is composed of the body of 15 independent judges. No two of them may be nationals of the same country, and they should be "elected regardless of their nationality from among persons of high moral character, who possess the qualifications required in their respective countries for appointment to the highest judicial offices, or are jurisconsults of recognized competence in international law" (Article 2 of the ICJ Statute). Candidates are nominated by the national groups in the Permanent Court of Arbitration. Judges are elected by the UN General Assembly (UNGA) and UN Security Council (UNSC) for the term of nine years, and are subject to re-election.

According to Article 9 of the ICJ Statute "...the electors shall bear in mind not only that the persons to be elected should individually possess the qualifications required, but also that in the body as a whole the representation of the main forms of civilization and of the principal legal systems of the world should be assured". In practice, this representation means that judges are elected from UN regional groups: Africa and Asia are allowed three positions, the Latin American and Caribbean Groups have two, Eastern Europe has two positions (in practice, one of those "belongs" to Russia), and Western Europe and other Groups have five positions. All the permanent members of the UNSC almost always had a judge of their nationality in the Court (this is an informal rule and till 2017 the only exception to this rule was China, between 1967 and 1985; in 2017, UK lost "its" place for the first time in the Court history). The Court elects President and Vice-President of the Court for a term of three years, and they may be re-elected (in practice, however, no one was ever re-elected to the position of President of the Court). According to Article 55 of the Statute, all matters are decided by a majority vote of the present judges; in the event of an equal number of votes, the Court President casts the deciding vote.

After briefly describing the formal procedure of the nomination and election of the Court judges, the scene is set for the explanation of the role of Eastern European judges in the World Court. The PCIJ and the ICJ have had about 140 judges altogether. If one does not count the Russian judges as coming from Eastern Europe (and there are good reasons not to do so because Russia, as a permanent member of Security Council, has had one "guaranteed" place), nine judges from this part of the world had served in the World Court to date (Table 1). Even though this figure does not seem exactly impressive, considering the fact that practically there could be only one judge from Eastern Europe at a time, and that Bohdan Winiarski and Manfred Lachs served as judges for 47 years combined, the number becomes rather understandable. There have been four 
Eastern European judges that served at the PCIJ, and five at the ICJ (Judge Peter Tomka is still a judge of ICJ).

Table 1: Eastern European judges that served at the World Court (1922- to date)

\begin{tabular}{|l|l|l|l|l|}
\hline \multicolumn{1}{|c|}{ Name } & \multicolumn{1}{|c|}{ Country } & \multicolumn{1}{c|}{ Term } & \multicolumn{1}{c|}{$\begin{array}{c}\text { Vice- } \\
\text { President }\end{array}$} & President \\
\hline $\begin{array}{l}\text { Mihailo } \\
\text { Jovanovic }\end{array}$ & $\begin{array}{l}\text { Serb-Croat-Slovene } \\
\text { Kingdom }\end{array}$ & $\begin{array}{l}\text { Deputy Judge 1922- } \\
1930\end{array}$ & & \\
\hline $\begin{array}{l}\text { Demetru } \\
\text { Negulesco }\end{array}$ & Romania & $\begin{array}{l}\text { Deputy Judge 1922- } \\
1930 ; \text { Judge 1931- } \\
1942\end{array}$ & & \\
\hline $\begin{array}{l}\text { Mileta } \\
\text { Novakovic }\end{array}$ & $\begin{array}{l}\text { Serb-Croat- } \\
\text { (Yugene Kingdom }\end{array}$ & $\begin{array}{l}\text { Deputy Judge 1931- } \\
1936\end{array}$ & & \\
\hline $\begin{array}{l}\text { Michal } \\
\text { Rostworowski }\end{array}$ & Poland & Judge 1931-1940 & & \\
\hline $\begin{array}{l}\text { Milovan } \\
\text { Zoricic }\end{array}$ & Yugoslavia & $1946-1958$ & & $1961-$ \\
\hline $\begin{array}{l}\text { Bohdan } \\
\text { Winiarski }\end{array}$ & Poland & $1946-1967$ & $\begin{array}{l}1973- \\
1976\end{array}$ \\
\hline $\begin{array}{l}\text { Manfred } \\
\text { Lachs }\end{array}$ & Poland & $1967-1993$ & $2009-$ & $\begin{array}{l}2012- \\
2015\end{array}$ \\
\hline Geza Hercegh & Hungary & $1993-2003$ & 2012 & \\
\hline Peter Tomka & Slovakia & $2003-$ to date & & \\
\hline
\end{tabular}

Source: International Court of Justice (2019); https://www.icj-cij.org/en/all-members

The majority of the Eastern Europe judges came from Poland and Yugoslavia (three from each country), while Romania, Hungary and Slovakia had one judge each. Arguably, the most prominent Eastern European judge at the PCIJ was Judge Demetru Negulesco from Romania, who had served for 20 years (actually throughout the entire period of operation of the Court). In one of his Presidential Statements, Judge Peter Tomka said that Negulesco's "contributions to the work of that pioneering international judicial institution and to the development of its jurisprudence were considerable and remain a source of inspiration for our Court today". ${ }^{23}$

It is probably interesting to note that, before taking the positions at the Court, the PCIJ judges coming from Eastern Europe were notable diplomats of their respective countries and educated in Paris. Most of them were professors of

23 Available at: http://www.icj-cij.org/files/press-releases/8/17258.pdf. 
international law in their countries (Negulesco, Novakovic, Rostworowski). Mileta Novakovic was, for example, the author of the first Public International Law textbook written in Serbian language (Novakovic, 1936). Negulesco and Jovanovic were judges in the national courts of Romania and Kingdom of Serbs, Croats and Slovenes, respectively.

Still, the best known judge among those listed in Table 1 is Judge Manfred Lachs. He was a Polish writer, diplomat and jurist. Lachs had earned his law degree at the Jagiellonian University of Krakow and had graduated from the London School of Economics before the outbreak of World War II. After the War, he had held several professional positions at the Ministry of Foreign Affairs of Poland. In 1966, Lachs became a judge of the ICJ and remained in that position until 1993. No one in the history of the Court served as a judge for such a long period of time. He was also President of the Court from 1973 to 1976. Therefore, it is not strange that Edward MacWhinney decided to dedicate a book to his legacy (MacWhinney, 1995a). In the book, MacWhinney noted that, notwithstanding Lachs' intellectual cosmopolitanism and eclectic legal education

"the political constraints of being a national of, in his own terms a nation on wheels, squeezed between Germany and Russia and with continuing Soviet and military presence, may be evident in certain aspects of his approach to decisionmaking... Lachs' way of life as high level official and adviser in Communist Poland may have taught him to weigh his words and try to use his skills of persuasion rather than make an outright break with formal dissent" (Lachs had reported only two dissenting opinions during his office). (MacWhinney, 1995: 10)

Lachs became President of the Court during his first term of office (1973-1976), which is important because it gave him an opportunity to become even more directly involved in the process of deliberating the Court's decisions in the period of the shift from the "old" to the "new" Court: "Within the United Nations legal community, Lachs was also widely seen as being an intellectual bridge between that positivistic, black letter law, purportedly political neutral approach of the "old" Court majority that had dominated the International Court's post-war jurisprudence, to a new, consciously purposive, policy-oriented approach..." (MacWhinney, 1995b: 217). Namely, Article 6 of the Resolution stipulates, concerning the internal judicial practice of the Court, that "on the basis of the views expressed in the deliberations and in the written notes, the Court proceeds to choose a drafting committee by secret ballot and by an absolute majority of votes of the judges present... The President shall ex officio be a member of the drafting committee unless he does not share the majority opinion of the Court as it appears then to exist" (Bedjaoui, 1991). Exceptionally important rulings, 
such as the North Sea Continental Shelf, ${ }^{24}$ and Legal Consequences for States of the Continued Presence of South Africa in Namibia ${ }^{25}$ were rendered during Lachs' term as President of the Court.

Lachs, however, was not the only judge from Eastern Europe who was President of the Court. The Court was also led by Judge Bohdan Winiarski (1961-1964) and Judge Peter Tomka (2012-2015), who is still serving in the Court. This means that Eastern Europeans occupied the important position of Court President in three terms (more than the number of presidential terms served by judges from Africa, equal to the number of terms served by judges from Middle and North America and Latin America, and only one term less than judges from Asia). Yet, judges from Eastern Europe had an important impact on the practice of the Court even when they did not occupy the position of President. One such judge was Judge Herczegh from Hungary: "There he became member of the silent majority: he was very proud of his participation in the drafting committee of most of the great cases of the ICJ which explains why he was the author of only a few dissenting opinions" (Kovacs, 2011: foreword).

As previously stated, the current ICJ judge coming from Eastern Europe is Peter Tomka, who was a President of the Court from 2012 till 2015 and he is currently serving his second mandate as a judge since he was elected in 2003. Judge Tomka was a legal adviser in Ministry of Foreign Affairs of Czechoslovakia and Slovakia, but also a Lecturer at Charles University, Prague. Like several other ICJ judges, he previously occupied a number of important positions in the UN or the League of Nations system (Tomka was Second Vice-Chairman of International Law Commission, Vice-Chairman of Sixth Legal Committee of UN General Assembly, etc.) which seems to be an important asset during the process of selection of ICJ judges.

\section{Conclusion}

The contribution of the World Court to the development of international law is difficult to overstate. As the PCIJ was the first standing international judicial institution, it had an opportunity to go even further: this Court was one of the most important factors in the development of international legal argument (the deep structure of international law). Therefore, the fact that approximately $50 \%$ of the PCIJ cases were closely connected with the Eastern European issues is not without significance.

24 International Court of Justice, North Sea Continental Shelf (Judgment) [1969] ICJ Rep 3.

25 International Court of Justice, Legal Consequences for States of the Continued Presence of South Africa in Namibia (South West Africa) notwithstanding Security Council Resolution 276 (Advisory Opinion) [1971] ICJ Rep 16. 
The Eastern European cases handled by the PCIJ pushed the development of many fundamental concepts of international law, such as sovereignty or the role of consent in international adjudication. Many would say that these are the exact positions of the PCIJ that had failed to stand the test of time, but they were crucial for the early development of the discipline. Additionally, the most concrete contribution of the PCIJ was in the area of treaty law, especially in the interpretation of international treaties and this contribution has enduring significance.

The caseload of the ICJ was not marked by Eastern European issues to the same extent. That was, yet again, the consequence of extra-legal factors. Notwithstanding this fact, some exceptionally important Eastern European cases have passed before the ICJ, such as the very first case tried before this Court - the famous Corfu Channel case. Almost fifty years after the Corfu Channel case, ICJ was the stage of fierce political and legal battle of the Yugoslav armed conflicts, as there have been two genocide cases that involved Eastern European countries. This fact gave the Court the first opportunity to clarify actus reus and mens rea of the crime of genocide and, of course, the liability of states for the violation of the Genocide Convention. The Court also had an opportunity to discuss the Kosovo issue in the Advisory Opinion on the Declaration of Independence, but the final impact of this Advisory Opinion remained limited.

The great significance of Eastern Europe for the development of international law is further supported by personal and professional biographies of Eastern Europeans who served in the World Court. Most of them not only actively participated in the historical cases before the PCIJ and the ICJ, but were also Presidents of the Court and members of the drafting committees at the time. Therefore, their impact on the development of international law should never be underestimated.

All these conclusions strongly support the argument presented at the beginning of the paper - Eastern Europe had a significant impact on the development of international law and the nickname "Thumbelina" is not appropriate one - one could even be tempted to add to this sentence the word unfortunately. Namely, due to the persistent politics of foreign interventions (armed and non-armed) and non-consistent application of general political and legal principles, especially by the major powers, Eastern Europe sustained great suffering and was a subject of strong international law interest. The fact that some brave and knowledgeable international lawyers were among the most important judges of the World Court represent an honour to the small community of international legal scholars in Eastern Europe, but fails to provide general comfort to people from this region. 


\section{References}

Bannelier, K. (2012). Foundational Judgment or Constructive Myth? The Court's Decision as a Precursor to Environmental International Law. In K. Bannelier, T. Christakis, S. Healthcote (eds.), The ICJ and the Evolution of International Law: the Enduring Impact of the Corfu Channel Case, New York: Routledge.

Bederman, D. J., Lathorp, C. G. (2009). Maritime Delimitation in the Black Sea (Romania v. Ukraine). The American Journal of International Law 103 (3). 543-549.

Bedjaoui, M. (1991). The "Manufacture" of Judgments in the International Court of Justice. Peace International Law Review 3 (1).

Bedjaoui, M. (2012). An International Contentious Case on the Threshold of the Cold War. In K. Bannelier, T. Christakis, S. Healthcote (eds.), The ICJ and the Evolution of International Law: the Enduring Impact of the Corfu Channel Case, New York: Routledge.

Behrens, P. (2015). Between Abstract event and Individualized Crime: Genocidal Intent in the Case of Croatia. Leiden Journal of International Law 28(4). 923-935.

Cassese, A. (2007). The Nicaragua and Tadic Test Revisited in Light of the ICJ Judgment on Genocide in Bosnia. The European Journal of International Law 18 (4). 649-668.

D’Argent, P. (2012). Reparations and Compliance. In K. Bannelier, T. Christakis, S. Healthcote (eds.), The ICJ and the Evolution of International Law: the Enduring Impact of the Corfu Channel Case, New York: Routledge.

Davies, N. (2005). God's Playground: A History of Poland, Vol. 2, Oxford: Oxford University Press.

Del Mar, K. (2012). The International Court of Justice and Standards of Proof. In K. Bannelier, T. Christakis, S. Healthcote (eds.), The ICJ and the Evolution of International Law: the Enduring Impact of the Corfu Channel Case, New York: Routledge.

Fachiri, A. P. (1929). Interpretation of Treaties. The American Journal of International Law 23 (4). 745-764.

Fitzmaurice, M., Tams, C. J. (eds.) (2013). Legacies of the Permanent Court of International Justice, Leiden/Boston: Martinus Nijhoff Publishers.

Gattini, A. (2007). Breach of the Obligation to Prevent and Reparation Thereof in the ICJ's Genocide Judgment. The European Journal of International Law 18 (4). 695-713. 
Hrnjaz, M. (2012). Odnos prava na samoopredeljenje i teritorijalnog integriteta država: podnesci povodom Savetodavnog mišljenja o Kosovu. U R. Nakarada, D. Živojinović, Srbija u evropskom i globalnom kontekstu, Beograd: Univerzitet u Beogradu - Fakultet političkih nauka. (191-213).

Kovacs, P. (ed.). (2011). International Law - A Quiet Strength, Miscellanea in memoriam Géza Herczegh, Budapest: Pazmany Press.

Kress, C. (2007). The International Court of Justice and the Elements of the Crime of Genocide, The European Journal of International Law 18 (4). 619-629.

Lachs, M. (1987). The Teacher in International Law: Teachings and Teaching, second edition. Dordrecht: Martinus Nijhoff Publishers.

MacWhinney, E. (1995a). Judge Manfred Lachs and Judicial Law-making: opinions on the International Court of Justice, 1967-1993, Leiden/Boston: Martinus Nijhoff Publishers.

MacWhinney, E. (1995b). The Role and Mission of the International Court in an Era of Historical Transition. In N. Jasentuliyana, Perspectives on International Law, London: Kluwer Law International.

McLaughlin,R. (2012). Dangerous waters and International Law: the Corfu Channel case, Warships, and Sovereignty Irritants. In K. Bannelier, T. Christakis, S. Healthcote (eds.), The ICJ and the Evolution of International Law: the Enduring Impact of the Corfu Channel Case, New York: Routledge.

Milanovic, M. State Responsibility for Genocide: A Folllow-Up. The European Journal of International Law 18 (4). 669-694.

Milanovic, M., Wood, M. (eds.) (2015). The Law and Politics of the Kosovo Advisory Opinion, Oxford: Oxford Univeristy Press.

Novakovic, M. (1936-1938). Osnovi medjunarodnog javnog prava, vol. I i II, Beograd: Privrednik.

Prazmowska, A. J. (2011). History of Poland ( $2^{\text {nd }}$ edition), London: Red Globe Press.

Spiermann, 0. (2004). International Legal Argument in the Permanent Court of International Justice: The Rise of International Judiciary, Cambridge: Cambridge University Press.

Steiner, H. A. (1936). Fundamental Conceptions of International Law in the Jurisprudence of Permanent Court of International Justice, The American Journal of International Law 30 (3). 414-438. 
Steinfeld, M. (2015). When Ethnic Cleansing is not Genocide: A Critical Appraisal of the ICJ's ulling in Croatia v. Serbia in relation to Deportation and Population Transfer. Leiden Journal of International Law 28 (4). 937-944.

Terris D., Romano C. P. R., Swigart, L. (2007). The International Judge: An Introduction to the Man and Woman Who Decide the World's Cases. Hanover: University Press of New England.

International Court of Justice (2019): http://www.icj-cij.org; https://www.icjcij.org/en/all-members

(accessed 1.2.2019)

\section{Judgments and Advisory Opinions of the PCIJ and ICJ}

International Court of Justice, Corfu Channel case (United Kingdom v. Albania (Judgment), [1949], ICJ Rep 22.

International Court of Justice, Interpretation of Peace Treaties (Advisory Opinion) [1950] ICJ Rep 65.

International Court of Justice, Legal Consequences for States of the Continued Presence of South Africa in Namibia (South West Africa) notwithstanding Security Council Resolution 276 (Advisory Opinion) [1971] ICJ Rep 16.

International Court of Justice, Legal Consequences of the Construction of the Wall in the Occupied Palestinian Territory (Advisory Opinion) [2004] ICJ Rep 136.

International Court of Justice, North Sea Continental Shelf (Judgment) [1969] ICJ Rep 3.

International Court of Justice: Accordance with International Law of the Unilateral Declaration of Independence in Respect of Kosovo (Advisory Opinion) [2010] ICJ Rep 403.

International Court of Justice: Application of the Convention on the Prevention and Punishment of the Crime of Genocide (Croatia v. Serbia) (Judgment) [2015] ICJ Rep 3.

International Court of Justice: Application of the Convention on the Prevention and Punishment of the Crime of Genocide (Bosnia and Herzegovina v. Serbia and Montenegro) (Judgment) [2007] ICJ Rep 43.

Permanent Court of International Justice, Case Concerning the Factory at Chorzow (Merits) [1928] Series A.

Permanent Court of International Justice, Case Concerning the Payment of Various Serbian Loans Issued in France (Judgment) [1929] Series A. 
Permanent Court of International Justice, Case of the S.S. Wimbledon (Judgment) [1923] Series A.

Permanent Court of International Justice, German Settlers in Poland (Advisory Opinion) [1923] Series B.

Permanent Court of International Justice, Jurisdiction of the European Commission on the Danube (Advisory Opinion) [1927] Series B.

Permanent Court of International Justice, Question of Jaworzina (Advisory Opinion) [1923] Series B.

Permanent Court of International Justice, Question of Monastery Saint-Naoum (Advisory Opinion) [1924] Series B.

Permanent Court of International Justice, The Greco-Bulgarian "Communities" (Advisory Opinion) [1930] Series B.

Permanent Court of International Justice, Treatment of Polish Nationals and other Persons of Polish Origin or Speech in the Danzig Territory (Advisory Opinion) [1932] Series A/B.

\title{
Др Милош Хрњаз,
}

Универзитет у Београду,

Доцент Факултета политичких наука

\section{ИСТОЧНА ЕВРОПА ПРЕД СВЕТСКИМ СУДОМ: “ПАЛЧИЦА” МЕЪУНАРОДНОГ ПРАВНОГ ПОРЕТКА?}

\begin{abstract}
Резиме
Источна Европа представља релативно мали регион у светским размерама. Показује се, међутим, да је значај овог региона у погледу изградње међународног правног поретка изразито несразмеран његовој величини. У раду се конкретније истражује утицај источноевропских питања и судија Светског суда који су дошли из овог региона на развој међународног права. Користећи више квалитативних и квантитативних индикатора попут броја пресуда овог Суда који се тищао Источне Европе, броја судија који су долазили из овог региона, периода током којих су источноевропске судије биле председнищи Суда, као и значаја појединих пресуда за изградњу међународноправног поретка, у раду се долази до закључка да је регион имао велики значај за развој међународног права.
\end{abstract}

Кључне речи: Међународни суд правде, Стални суд међународне правде, Источна Европа, развој међународног права, судије Међународног суда правде. 